\title{
In vitro antioxidant and In vivo Anti-inflammatory Potentials of Marantochloa Leucantha (Marantaceae) Extracts and Fractions
}

\author{
Wilfred O. Obonga, Charles O. Nnadi, Chinonye C. Chima, \\ Sunday N. Okafor and Edwin 0. Omeje
}

Department of Pharmaceutical and Medicinal Chemistry, Faculty of Pharmaceutical Sciences University of Nigeria Nsukka, 410001 Nsukka Nigeria

(Received: December 25, 2018; Accepted: September 3, 2019; Published (Web): December 19, 2019)

\begin{abstract}
This study evaluated the antioxidant and anti-inflammatory properties of Marantochloa leucantha (Marantaceae). The in vitro antioxidant activity of the extracts and solvent fractions was evaluated by 1,1-diphenyl2-picrylhydrazyl (DPPH) radical scavenging and ferric reducing antioxidant potential (FRAP) assay models and in vivo anti-inflammatory activity by the rat paw edema model. The phytochemical screening indicated the presence of tannins, terpenoids, steroids, flavonoids, reducing sugar and phenolics. The antioxidant assay showed that all the extracts exhibited high antioxidant activity comparable with ascorbic and gallic acid controls. In DPPH model, a $250 \mu \mathrm{g} / \mathrm{ml}$ EtOAc fraction of the leaves showed antioxidant activity of $93.9 \pm 1.7 \%\left(\mathrm{EC}_{50} 0.82 \mu \mathrm{g} / \mathrm{ml}\right)$ and a 1000 $\mu \mathrm{g} / \mathrm{ml}$ of same stem fraction produced $91.9 \pm 0.3 \%$ activity $\left(\mathrm{EC}_{50} 1.38 \mu \mathrm{g} / \mathrm{ml}\right)$. In the FRAP model, EtOAc fraction exhibited $31.1 \pm 0.7$ and $92.0 \pm 2.2 \mu \mathrm{M} \mathrm{Fe}^{2+} / \mathrm{g}$ of dried leaves and stem, respectively at $1000 \mu \mathrm{g} / \mathrm{ml} \mathrm{FeSO}_{4}$ equivalent. The anti-inflammatory potential of the plant showed that the crude stem extract and fractions at $200-600 \mathrm{mg} / \mathrm{kg}$ exhibited significant $(p<0.01)$ dose-related inhibition of paw edema in rats. A $200 \mathrm{mg} / \mathrm{kg}$ EtOAc fraction showed $18.8 \%$ inhibition compared to $31 \%$ observed in diclofenac-treated rats in $2 \mathrm{~h}$ post albumin challenge. These findings validated the folkloric use of this plant in the treatment of diseases associated to the oxidative stress and could further provide promising lead compounds with potent antioxidant and anti-inflammatory activities.
\end{abstract}

Key words: Radical scavenging, ethnopharmacology, Marantochloa, inflammation.

\section{INTRODUCTION}

The use of different plant parts for therapeutic and medicinal purposes especially in Africa has been on the increase due to their availability, accessibility and affordability. ${ }^{1,2}$ The WHO has estimated that 85 percent of traditional medicine involves use of such plant extracts, especially in Africa and $\mathrm{Asia}^{3,4}$ and one of such plant is the Marantochloa leucantha of the Marantaceae family. M. leucantha, commonly called Yoruba soft cane, Nkong Aya or akwukwo Uma in Nigeria, is widely used in African traditional medicines (ATMs). Its ethno-therapeutic relevance cuts across Africa. ${ }^{5}$ The root pulp is used in Ivory

Correspondence to: Charles O. Nnadi

E-mail: charles.nnadi@unn.edu.ng

Telephone: +2348064947734

Dhaka Univ. J. Pharm. Sci. 18(2): 233-240, 2019 (December) DOI: https://doi.org/10.3329/dujps.v18i2.44463
Coast as a dressing on abscesses, chancres and glandular swellings to soothe pain and to promote cicatrization. ${ }^{5}$ The leaf sap, aqueous decoction or alcoholic infusion of pulverized leaves is drunk in epilepsy or other brain disorders. Aside the aforementioned uses in addition to several potential biologically active phytochemical constituents have been identified in Marantaceae ${ }^{6-11}$, there has been claims of its use in Southern Nigeria and across Africa for the management of autoimmune diseases such as rheumatoid arthritis and oxidative stress. ${ }^{12,13}$ Inflammation, whether acute or chronic, is the response of living tissue to injury and harmful stimuli and it involves a complex array of enzyme activation, mediator release, cell migration, tissue breakdown and repair. ${ }^{14,15}$ Though a defense mechanism, it can induce, maintain or aggravate many diseases 
especially when unchecked. ${ }^{16,17}$ The link between inflammation and diseases like bronchitis, ulcerative colitis, rheumatoid arthritis, hepatitis and angina have awakened researcher's interest and focus in inflammation and remedies despite breakthroughs in anti-inflammatory orthodox medicines. More so, the non-steroidal anti-inflammatory drugs (NSAIDs) have been discovered to pose challenges in kidney function while many chemical compounds are involved in the promotion and resolution of the inflammatory process. ${ }^{18}$ There is, therefore, strong need via complementary and alternative medicines to discover more available, affordable and accessible drugs with lower or least noxious effects. ${ }^{2}$ The treatment of inflammation and disorder of oxidative stress (with plants including $M$. leucantha) is an area of practice in which African traditional and complementary medicine (ATCM) practitioner relish success and patronage. ${ }^{19,20}$ Till date, these known applications and potentials of M. leucantha have not been scientifically validated despite its popularity and widespread use in Southern Nigeria and beyond. ${ }^{5}$ Moreover, the virginity of this plant in ATCM deserves extensive research to back up the claims on the ethnopharmacological relevance of the plant.

\section{MATERIALS AND METHODS}

Equipment, chemicals and reagents. Methanol, dichloromethane, EtOAc, $n$-hexane and $n$-butanol were purchased from Sigma-Aldreich; iron (III) chloride, Fehling solution, glacial acetic acid, Mayer's Reagent, acetic anhydride, sulphuric acid, chloroform and sodium hydroxide used for the phytochemical analysis were of analytical grades. Standard drugs: ascorbic acid (G\&G, UK), gallic acid (Carbone Sci. Co., UK) and diclofenac (Bliss GVS Pharma, India) were used as controls. Unless otherwise stated, all reagents were used as procured. A UV-Visible Spectrophotometer (Qiaopu, China) was used for all spectrophotometric analysis.

Plant materials. The fresh leaves and stem of M. leucantha were collected from Akwa Ibom $\left(4^{\circ} 32\right.$ and $5^{\circ} 33 \mathrm{~N}$, and $7^{\circ} 25$ and $8^{\circ} 25 \mathrm{E}$ ), Nigeria in November 2017. The plant was identified and authenticated by Mr. Felix Nwafor, a taxonomist at the Institute of Pharmacognosy and Environmental Medicine, University of Nigeria Nsukka. The voucher specimen (number PCG/UNN/0097) was deposited at the herbarium unit of the Institute. The plant materials were dried under shade and ground to $1 \mathrm{~mm}$ particle sizes.

Animals. Swiss albino rats (120-170 g) and mice (17-40 g) of either sex used for the experiments were purchased from the animal house of the Department of Pharmacology, University of Nigeria Nsukka. The animals were kept in clean and well ventilated cages. Standard feed and clean drinking water were given ad libitium.

Extraction of plant materials. $500 \mathrm{~g}$ each of the powdered plant materials was separately extracted by cold maceration in $95 \%(\mathrm{v} / \mathrm{v})$ methanol for $24 \mathrm{~h}$ with intermittent agitation in line with the method of preparation described by ATCM practitioners in Southern Nigeria. Thereafter, the mixture was filtered and the filtrate concentrated in vасиио using rotary evaporator. The resulting crude extracts were refrigerated at $4{ }^{\circ} \mathrm{C}$ until use.

Solvent-solvent fractionation of crude extract. A $13 \mathrm{~g}$ each of the methanol extract was re-dissolved in $500 \mathrm{~mL}$ of $10 \%(\mathrm{v} / \mathrm{v})$ aqueous methanol and separately partitioned successively in a $2 \mathrm{~L}$ separatory funnel using equal volumes of $n$-hexane, EtOAc, and $n$-butanol in increasing order of polarity of the solvents. All the six fractions were concentrated in vасиио to give the $n$-hexane, EtOAc and $n$-butanol fractions of the leaves and stem respectively.

Qualitative phytochemical evaluation. The methanol extract was tested for the phytochemical constituents such as glycosides, saponins, steroids, flavonoids, terpenoids, tannins, alkaloids and reducing sugar by standard protocol. ${ }^{21}$

Acute toxicity evaluation. The acute toxicity $\left(\mathrm{LD}_{50}\right)$ test of the extract was determined by Lorke's method. ${ }^{22}$ The first phase involved the determination of toxic range of the extracts using 3 groups of mice $(\mathrm{n}=3)$. Each group received 10, 100, $1000 \mathrm{mg} / \mathrm{kg}$ of the extract in $10 \%(\mathrm{v} / \mathrm{v})$ tween 80 orally. The 
animals were monitored for $24 \mathrm{~h}$ for gross behavioural changes and mortality. In the second phase, higher doses of 1600, 2900 and $5000 \mathrm{mg} / \mathrm{kg}$ of the extract were administered to fresh 3 mice at one dose per animal $(\mathrm{n}=1)$. The animals were also monitored for $24 \mathrm{~h}$ for death. The $\mathrm{LD}_{50}$ was calculated as the geometric mean of the maximum dose that caused $0 \%$ death and the minimum dose that caused $100 \%$ death.

\section{Evaluation of in vitro antioxidant potential.}

(a) Quantitative DPPH radical scavenging assay: The scavenging activity of the extract and fractions on DPPH radicals was determined by the method of Gyamfi and co-workers ${ }^{23}$ with slight modification. A $1 \mathrm{ml}$ of the extract or fractions (15.6 - $1000 \mu \mathrm{g} / \mathrm{ml})$ in $80 \%(\mathrm{v} / \mathrm{v})$ methanol was mixed with $0.5 \mathrm{ml}$ of $0.076 \mathrm{mM}$ DPPH in methanol. The mixture was agitated vigorously and allowed to stand at room temperature in the dark for $25 \mathrm{~min}$. The negative control was $1 \mathrm{ml}$ of $0.076 \mathrm{mM}$ DPPH in methanol. $L$-ascorbic acid was used as the positive control. Thereafter, the absorbance of the mixture was measured at $517 \mathrm{~nm}$ using visible spectrophotometer. DPPH radical scavenging activity was calculated using the equation:

$\%$ Radical scavenging activity

$=1-\left[\frac{\text { Absorbance of Sample }}{\text { Absorbance of control }}\right] \times 100$ -

The $\mathrm{EC}_{50}$ value represented the concentration of the sample leading to $50 \%$ reduction in the initial DPPH concentration.

(b) Ferric reducing antioxidant potential assay: The reducing ability of the extract and its fractions was determined as previously described. ${ }^{24}$ A $2 \mathrm{ml}$ of the sample was mixed with $2 \mathrm{ml}$ of $0.2 \mathrm{M}$ phosphate buffer ( $\mathrm{pH}$ 6.6) and $2 \mathrm{ml}$ of $10 \mathrm{mg} / \mathrm{l}$ potassium ferricyanide solution. The mixture was incubated in a water bath at $50^{\circ} \mathrm{C}$ for 20 mins. There after, $2 \mathrm{ml}$ of $100 \mathrm{mg} / \mathrm{l}$ trichloroacetic acid solution was added. An aliquot of $2 \mathrm{ml}$ of the mixture was combined with 2 $\mathrm{ml}$ of distilled water and $0.4 \mathrm{ml}$ of $0.1 \%$ (w/v) ferric chloride $\left(\mathrm{FeCl}_{3} \cdot 6 \mathrm{H}_{2} \mathrm{O}\right)$ solution. The absorbance of the reaction mixture was measured at $700 \mathrm{~nm}$ after 10 mins of the reaction. The ferric reducing antioxidant potential of extract was expressed as $\mu \mathrm{M} / \mathrm{g}\left(\mathrm{Fe}^{2+}\right)$ of dry sample.

In vivo anti-inflammatory activity by paw edema model: The acute anti-inflammatory activity was investigated using the rat paw edema method as previously reported by Winter. ${ }^{25}$ The animals were fasted for a period of $12 \mathrm{hrs}$ before the experiment. The extract and fractions (200, 400 and $600 \mathrm{mg} / \mathrm{kg}$ ) or diclofenac $(10 \mathrm{mg} / \mathrm{kg})$ suspended in $10 \%(\mathrm{v} / \mathrm{v})$ tween 80 were administered to the rats orally. The negative control group received $10 \%$ tween 80 (3 $\mathrm{mL} / \mathrm{kg}$ ) orally. One hour post treatment, inflammation was induced by injecting $0.1 \mathrm{~mL}$ of fresh egg albumin into the subplantar surface of the left hind paw of rats. The left hind paw volumes of the rats were measured by water displacement before the experiment (zero time) and at $1 \mathrm{hr}$ intervals after the injection of egg albumin for a period of $5 \mathrm{hrs}$. The average edema at every interval was assessed in terms of difference in volume displacement after injecting the egg albumin and zero-time volume displacement of the injected paw $\left(\mathrm{V}_{\mathrm{t}}-\mathrm{V}_{\mathrm{o}}\right)$. Percentage inhibition of edema was calculated for each treated group using the formula

Percentage inhibition of edema $=\frac{v_{0}-V_{t}}{V_{o}} \times 100$

Where $V_{o}$ and $V_{t}$ are edema volume of negative control and treated groups, respectively at the corresponding time, $\mathrm{t}$.

Statistical analysis. Data obtained were presented as mean \pm SEM and analysed using oneway analysis of variance (ANOVA) and post-hoc comparisons were carried out using Dunnett's t-test on SPSS version 20. Values $p<0.05$ and/or $p<0.01$ were considered significant in the study

\section{RESULTS AND DISCUSSION}

The phytochemical analysis showed similarity in the phytochemical constituents of the stem and leaves of M. leucantha. Glycosides, alkaloids and saponins were conspicuously absent while tannins, terpenoids, steroids, flavonoids and phenolics were detected in slightly higher amounts in leaves compared with stem. These secondary metabolites are 
physiologically active compounds possessing great potential for therapeutic and preventive uses. Flavonoids, for instance, are widely distributed in plants and have been reported to display marked in vitro and in vivo anti-inflammatory properties. ${ }^{26}$ Therefore, it is possible that the anti-inflammatory and antioxidant effects observed with the extracts may be attributed to its flavonoids, terpenoid, steroids and phenolics constituents of the plant.

The safety of the plant extract was established by oral acute toxicity evaluation in which the intraperitoneal $\mathrm{LD}_{50} M$. leucantha was found to be $5000 \mathrm{mg} / \mathrm{kg}$. This showed that the intraperitoneal $\mathrm{LD}_{50}$ is within safety margins at $\mathrm{LD}_{50} \leq 5000 \mathrm{mg} / \mathrm{kg}$.
Antioxidant activities. The extract and fractions of the plant showed remarkable DPPH free radicals scavenging activities reaching statistically significant difference $(p<0.05)$ at lower concentration tested (data not shown for purpose of brevity). Both EtOAc and $n$-butanol fractions of the stem at concentration of $>250 \mu \mathrm{g} / \mathrm{ml}$ showed $>90 \%$ DPPH scavenging effect in comparison to ascorbic acid but slightly higher than the effect of the leaves. Interestingly, both EtOAc and $n$-butanol fraction of the leaves (Table 1) showed $\mathrm{EC}_{50}$ of 0.8 and $1.0 \mu \mathrm{g} / \mathrm{ml}$ respectively compared with $0.7 \mu \mathrm{g} / \mathrm{ml}$ of the control while $1.4 \mu \mathrm{g} / \mathrm{ml}$ and $1.2 \mu \mathrm{g} / \mathrm{ml}$ exhibited by the stem further confirming the higher antioxidant flavonoids and phenolic constituents observed in the leaves.

Table 1. Antioxidant $\mathrm{EC}_{50}$ of extracts and fractions of $M$. leucantha leaves and stem.

\begin{tabular}{llllllllll}
\hline Extracts & CES & HSS & ESS & BSS & CEL & HSL & ESL & BSL & Control \\
\hline $\begin{array}{l}\mathrm{EC}_{50}, \\
\mu \mathrm{g} / \mathrm{ml}\end{array}$ & $1.2 \pm 0.1$ & $1.4 \pm 0.1$ & $1.4 \pm 0.1$ & $1.2 \pm 0.0$ & $1.3 \pm 0.1$ & $1.1 \pm 0.0$ & $0.8 \pm 0.1$ & $1.0 \pm 0.0$ & $0.7 \pm 0.1$ \\
\hline
\end{tabular}

Data expressed as Mean \pm SEM, CES, HSS, ESS, and BSS represent $M$. leucantha stem extract, $n$-hexane, EtOAc and $n$-butanol fractions respectively and CEL, HSL, ESL, and BSL represent $M$. leucantha leaves extract, $n$-hexane, EtOAc and $n$-butanol fractions respectively.

Interestingly also, the DPPH inhibition by the EtOAc fraction of leaves was slightly higher $(93.9 \pm$ $1.7 \%)$ at $250 \mu \mathrm{g} / \mathrm{ml}$ compared with ascorbic acid $(91.7 \pm 0.5)$ at the same concentration. More so, $n$ butanol and $n$-hexane fractions showed $90.1 \pm 1.1$ and $75.6 \pm 0.5 \%$, respectively at the same concentration. However, comparable effects of 91.9 $\pm 0.3,90.6 \pm 0.2$ and $81.0 \pm 1.6 \%$ were observed for EtOAc, $n$-butanol and $n$-hexane fractions, respectively at $1000 \mu \mathrm{g} / \mathrm{ml}$. The obviously higher free radical scavenging ability of the moderately polar EtOAc fraction indicates the presence of rich protic flavonoids higher than in the $n$-hexane fraction. ${ }^{27}$ This differential radical scavenging activity of extracts and solvent fractions could also be related to the nature of phenolics and flavonoids which are known to facilitate their electron transfer or hydrogen donating ability. ${ }^{27,28}$

To further confirm the antioxidant potential of this plant, FRAP evaluation was conducted. The invitro activities appeared to be dependent on the polarity of the extraction solvent (Tables 2 and 3). In both cases, the EtOAc fractions showed higher activities in the FRAP models though there was no statistical significant difference $(p<0.05)$ between the effects of extracts and $n$-hexane fractions. There was also lower FRAP effect of all tested substances compared with gallic acid control.

The antioxidant compounds are known to reduce ferric $\left(\mathrm{Fe}^{3+}\right)$ to ferrous $\left(\mathrm{Fe}^{2+}\right)$ form by formation of measurable blue colored complex at $700 \mathrm{~nm}$ in FRAP model. Its robustness in this regard demonstrated usefulness in antioxidant activity assays. ${ }^{29}$ Similar to the DPPH effects, the moderately polar EtOAc fractions of $M$. leucantha exhibited antioxidant potential higher than the $n$-hexane soluble. This model, however, showed that the stem extracts possessed higher reducing potential $(92.0 \pm 2.2 \mu \mathrm{M}$ $\mathrm{Fe}^{2+} / \mathrm{g}$ ) than the leaves but could still be attributed to high content of flavonoids and phenolics. ${ }^{27,28}$ More so, the slight antioxidant effect of the $n$-hexane fraction $\left(60.7 \mu \mathrm{M} \mathrm{Fe}^{2+} / \mathrm{g}\right.$ for stem; $29.8 \mu \mathrm{M} \mathrm{Fe}^{2+} / \mathrm{g}$ for leaves) could be attributed to their terpenoids constituents. $^{24}$ The reducing potential could be 
associated with the presence of compounds which exert their action by breaking the free radical chain through donating a hydrogen atom. ${ }^{28}$ The ability of extract to reduce iron, in these cases, suggests that they contain compounds that are electron donors, ${ }^{27}$ which can react with free radicals to convert them to more stable products and terminate radical chain reaction an indication of the presence of inhibitory compounds as a result of FRAP activity in different extracts. A related study by Ikram et al. and Fu et al. showed a FRAP of $0.67 \mu \mathrm{M} \mathrm{Fe} e^{2+} / \mathrm{g}$ of Areca triandra, ${ }^{30,31}$ a value slightly comparable with FRAP of $M$. leucantha leaves $\left(0.64 \mu \mathrm{M} \mathrm{Fe} e^{2+} / \mathrm{g}\right)$ at 62.5 $\mu \mathrm{g} / \mathrm{ml}$ in this study.

Anti-inflammatory activities. The results of anti-inflammatory evaluation showed that the crude stem extract and fractions of M. leucantha at doses of
200, 400, and $600 \mathrm{mg} / \mathrm{kg}$ exhibited significant $(p<$ $0.05, p<0.01)$ dose-dependent inhibition of paw edema in rats (Table 4). Here, the stem extract of $M$. leucantha at doses of 400 and $600 \mathrm{mg} / \mathrm{kg}$ showed significant $(p<0.01)$ inhibition of egg albumin induced edema $2 \mathrm{~h}$ post-induction. However, at dose of $200 \mathrm{mg} / \mathrm{kg}$ the extract significantly inhibited albumin induced edema $(p<0.01)$ after 2,4 and $5 \mathrm{~h}$ of observation compared to the control group.

The EtOAc fraction at dose of $200 \mathrm{mg} / \mathrm{kg}$ exhibited inhibition of $18.8 \%$ compared with $31 \%$ in control $2 \mathrm{~h}$ post-albumin challenge (Table 5). At 5 $\mathrm{h}$, both EtOAc and $n$-butanol fractions showed significant $(p<0.05 ; p<0.01)$ inhibition of paw edema in rats; 56.7 and $40 \%$ respectively compared with $42.9 \%$ inhibition recorded in diclofenac-treated rats.

Table 2. Ferric reducing antioxidant potential of leaves of $M$. leucantha.

\begin{tabular}{lcccc}
\hline $\begin{array}{l}\text { Concentration } \\
(\mu \mathrm{g} / \mathrm{ml})\end{array}$ & $\begin{array}{c}\text { Crude extract }(\mu \mathrm{M} \\
\left.\mathrm{Fe}^{2+} / \mathrm{g}\right)\end{array}$ & $\begin{array}{c}n \text {-Hex fraction } \\
\left(\mu \mathrm{M} \mathrm{Fe}^{2+} / \mathrm{g}\right)\end{array}$ & $\begin{array}{c}\text { EtOAc fraction } \\
\left(\mu \mathrm{M} \mathrm{Fe}^{2+} / \mathrm{g}\right)\end{array}$ & $\begin{array}{c}\text { Gallic acid } \\
\left(\mu \mathrm{M} \mathrm{Fe}^{2+} / \mathrm{g}\right)\end{array}$ \\
\hline 15.63 & $0.34 \pm 0.03$ & $0.13 \pm 0.05$ & $0.20 \pm 0.03$ & $0.86 \pm 0.05$ \\
31.25 & $0.58 \pm 0.06$ & $0.20 \pm 0.11$ & $0.40 \pm 0.02$ & $3.01 \pm 0.51$ \\
62.5 & $0.75 \pm 0.42$ & $0.47 \pm 0.02$ & $0.64 \pm 0.05^{\mathrm{a}}$ & $4.62 \pm 0.68$ \\
125 & $3.33 \pm 0.66^{\mathrm{a}}$ & $1.07 \pm 0.16$ & $1.41 \pm 0.18^{\mathrm{a}}$ & $10.45 \pm 1.29$ \\
250 & $5.11 \pm 0.89^{\mathrm{a}}$ & $3.02 \pm 0.68^{\mathrm{a}}$ & $2.82 \pm 0.30^{\mathrm{a}}$ & $31.31 \pm 4.12$ \\
500 & $6.71 \pm 1.05^{\mathrm{a}}$ & $10.50 \pm 1.34^{\mathrm{a}}$ & $9.24 \pm 0.26^{\mathrm{a}}$ & $60.96 \pm 4.21$ \\
1000 & $23.73 \pm 0.68^{\mathrm{a}}$ & $29.76 \pm 0.89^{\mathrm{a}}$ & $31.12 \pm 0.70^{\mathrm{a}}$ & $175.00 \pm 4.68$ \\
\hline
\end{tabular}

Mean \pm SEM, $\mathrm{n}=3 .{ }^{\mathrm{a}} p<0.05$ are significant compared to positive control group, $n$-hex and EtOAc represent $n$-hexane and EtOAc fractions of leaves of M. leucantha, respectively.

Table 3. Ferric reducing antioxidant potential of stem of M. leucantha.

\begin{tabular}{lcccc}
\hline $\begin{array}{l}\text { Concentration } \\
(\mu \mathrm{g} / \mathrm{ml})\end{array}$ & $\begin{array}{c}\text { Crude extract } \\
\left(\mu \mathrm{M} \mathrm{Fe}^{2+} / \mathrm{g}\right)\end{array}$ & $\begin{array}{c}n \text {-Hex fraction } \\
\left(\mu \mathrm{M} \mathrm{Fe}^{2+} / \mathrm{g}\right)\end{array}$ & $\begin{array}{c}\text { EtOAc fraction } \\
(\mu \mathrm{M} \mathrm{Fe} / \mathrm{g})\end{array}$ & $\begin{array}{c}\text { Gallic acid } \\
\left(\mu \mathrm{M} \mathrm{Fe}^{2+} / \mathrm{g}\right)\end{array}$ \\
\hline 15.63 & $0.19 \pm 0.03$ & $0.41 \pm 0.03$ & $0.39 \pm 0.01$ & $0.85 \pm 0.05$ \\
31.25 & $0.24 \pm 0.04$ & $0.91 \pm 0.06$ & $0.77 \pm 0.03$ & $3.01 \pm 0.51$ \\
62.5 & $0.66 \pm 0.03$ & $1.86 \pm 0.09$ & $1.88 \pm 0.16$ & $4.62 \pm 0.68$ \\
125 & $1.61 \pm 0.15$ & $3.70 \pm 0.20^{\mathrm{a}}$ & $5.06 \pm 0.31^{\mathrm{a}}$ & $10.45 \pm 1.29$ \\
250 & $5.01 \pm 0.26^{\mathrm{a}}$ & $7.44 \pm 0.34^{\mathrm{a}}$ & $10.80 \pm 0.67^{\mathrm{a}}$ & $31.31 \pm 4.12$ \\
500 & $18.58 \pm 1.29^{\mathrm{a}}$ & $20.91 \pm 1.52^{\mathrm{a}}$ & $30.83 \pm 1.26^{\mathrm{a}}$ & $60.96 \pm 4.21$ \\
1000 & $57.38 \pm 2.39^{\mathrm{a}}$ & $60.69 \pm 1.54^{\mathrm{a}}$ & $92.01 \pm 2.17^{\mathrm{a}}$ & $175.00 \pm 4.68$ \\
\hline
\end{tabular}

Mean \pm SEM, $\mathrm{n}=3{ }^{\mathrm{a}} p<0.05$ significant compared to positive control group, $n$-Hex and EtOAc represent $M$. leucantha stem $n$-hexane and EtOAc fractions respectively. 
Table 4. Anti-inflammatory effects of stem extract on rat paw edema.

\begin{tabular}{lccccc}
\hline Treatments, & \multicolumn{5}{c}{ Mean edema volume $(\mathrm{ml}) \pm \mathrm{SEM},(\%$ inhibition of edema) } \\
\cline { 2 - 6 } doses (mg/kg) & $1 \mathrm{hr}$ & $2 \mathrm{hrs}$ & $3 \mathrm{hrs}$ & $4 \mathrm{hrs}$ & $5 \mathrm{hrs}$ \\
\hline Control (tween 80) & $0.67 \pm 0.06$ & $0.66 \pm 0.04$ & $0.51 \pm 0.06$ & $0.49 \pm 0.03$ & $0.42 \pm 0.06$ \\
Crude extract, 200 & $0.53 \pm 0.02^{\mathrm{a}}$ & $0.46 \pm 0.01^{\mathrm{b}}$ & $0.42 \pm 0.01^{\mathrm{a}}$ & $0.27 \pm 0.02^{\mathrm{b}}$ & $0.24 \pm 0.01^{\mathrm{b}}$ \\
& $(28.9)$ & $(39.4)$ & $(17.6)$ & $(44.9)$ & $(42.9)$ \\
Crude extract, 400 & $0.53 \pm 0.02$ & $0.48 \pm 0.01^{\mathrm{b}}$ & $0.35 \pm 0.02$ & $0.31 \pm 0.04^{\mathrm{a}}$ & $0.21 \pm 0.04^{\mathrm{a}}$ \\
& $(28.9)$ & $(27.3)$ & $(31.4)$ & $(36.7)$ & $(50.0)$ \\
Crude extract, 600 & $0.56 \pm 0.03^{\mathrm{a}}$ & $0.51 \pm 0.02^{\mathrm{b}}$ & $0.46 \pm 0.02$ & $0.41 \pm 0.02^{\mathrm{a}}$ & $0.37 \pm 0.02^{\mathrm{a}}$ \\
& $(16.4)$ & $(22.7)$ & $(9.8)$ & $(16.3)$ & $(11.9)$ \\
Diclofenac, 10 & $0.51 \pm 0.03^{\mathrm{a}}$ & $0.45 \pm 0.03^{\mathrm{b}}$ & $0.38 \pm 0.05^{\mathrm{b}}$ & $0.29 \pm 0.05^{\mathrm{b}}$ & $0.24 \pm 0.03^{\mathrm{b}}$ \\
& $(23.9)$ & $(31.8)$ & $(25.5)$ & $(40.8)$ & $(42.9)$ \\
\hline
\end{tabular}

Data expressed as mean \pm SEM, ${ }^{\mathrm{a}} \mathrm{p}<0.05,{ }^{\mathrm{b}} \mathrm{p}<0.01,(\mathrm{n}=5)$ : Significant inhibition compared to negative control group.

Table 5. Anti-inflammatory effects of fractions of M. leucantha stem.

\begin{tabular}{llllll}
\hline \multirow{2}{*}{$\begin{array}{l}\text { Treatments, } \\
\text { doses }(\mathrm{mg} / \mathrm{kg})\end{array}$} & \multicolumn{5}{c}{ Mean edema volume $(\mathrm{ml}) \pm$ SEM, (\% inhibition of edema) } \\
\cline { 2 - 6 } & $1 \mathrm{hr}$ & $2 \mathrm{hrs}$ & $3 \mathrm{hrs}$ & $4 \mathrm{hrs}$ & $5 \mathrm{hrs}$ \\
\hline Control (tween 80) & $0.96 \pm 0.06$ & $0.80 \pm 0.02$ & $0.66 \pm 0.03$ & $0.64 \pm 0.04$ & 0.600 .03 \\
$n$-Hexane fraction, 200 & $0.78 \pm 0.04$ & $0.71 \pm 0.05$ & $0.59 \pm 0.03$ & $0.48 \pm 0.05^{\mathrm{a}}$ & $0.40 \pm 0.02^{\mathrm{a}}$ \\
& $(18.8)$ & $(10.4)$ & $(11.3)$ & $(25.0)$ & $(33.3)$ \\
EtOAc fraction, 200 & $0.76 \pm 0.03$ & $0.65 \pm 0.02^{\mathrm{a}}$ & $0.55 \pm 0.02^{\mathrm{a}}$ & $0.48 \pm 0.03^{\mathrm{a}}$ & $0.26 \pm 0.03^{\mathrm{b}}$ \\
& $(20.8)$ & $(18.8)$ & $(16.7)$ & $(25.0)$ & $(56.7)$ \\
$n$-Butanol fraction, 200 & $0.80 \pm 0.06$ & $0.81 \pm 0.07$ & $0.54 \pm 0.07$ & $0.51 \pm 0.09$ & $0.36 \pm 0.09^{\mathrm{a}}$ \\
& $(16.7)$ & $(12.5)$ & $(7.5)$ & $(20.3)$ & $(40.0)$ \\
Diclofenac, 10 & $0.51 \pm 0.03^{\mathrm{a}}$ & $0.45 \pm 0.03^{\mathrm{b}}$ & $0.38 \pm 0.05^{\mathrm{b}}$ & $0.29 \pm 0.05^{\mathrm{b}}$ & $0.24 \pm 0.03^{\mathrm{b}}$ \\
& $(23.9)$ & $(31.8)$ & $(25.5)$ & $(40.8)$ & $(42.9)$ \\
\hline
\end{tabular}

Data expressed as mean \pm SEM, ${ }^{a} \mathrm{p}<0.05,{ }^{\mathrm{b}} \mathrm{p}<0.01,(\mathrm{n}=5)$ : showed significant inhibition compared to negative control group.

The anti-inflammatory activity of extract and different fractions were found to suppress the development of paw edema induced by egg albumin in rats in a dose-dependent manner, comparable to diclofenac. The EtOAc stem fractions administered at a dose of $200 \mathrm{mg} / \mathrm{kg}$ produced a maximum percentage inhibition $(56.7 \%)$ and significantly inhibited $(\mathrm{p}<0.05)$ albumin induced paw edema, after $5 \mathrm{~h}$ of observation compared to the control group (42.9\% maximum inhibition). The fact that the moderately polar solvent (EtOAc) fraction of stem extract of M. leucantha at a dose of $200 \mathrm{mg} / \mathrm{kg}$ inhibited the inflammatory edema throughout the 5 hrs of observation may be explained by the fact that either the fractions has longer half life or is stable similar to diclofenac which not only inhibits initial inflammatory process where histamine, serotonin and kinin are the main mediators but also inhibited the edema up until $5 \mathrm{hrs}$ probably by inhibiting prostaglandin synthesis. ${ }^{32}$

\section{CONCLUSION}

Our study has validated the claimed use of $M$. leucantha in folkloric treatment of diseases associated with inflammatory disorders and oxidative stress. Against the claims however, the stem, compared with the leaves, extracts appeared to be more potent in both disease conditions. More so, biological activity-guided isolation of the active principles from the EtOAc fractions is currently ongoing and findings would be communicated elsewhere. This is expected to provide lead compounds with promising in-vitro antioxidant and in-vivo anti-inflammatory activities. 


\section{ACKNOWLEDGEMENT}

Authors acknowledge the ACTM practitioner and local users who provided the ethnopharmacological information that guided the authors in designing this study.

\section{REFERENCES}

1. Gupta, A.K., Vats, S.K. and Lal, B. 1998. How cheap can a medicinal plant species be? Curr. Sci. 74, 565-566.

2. Caccia-Bava, M.D.C.G., Bertoni, B.W., Pereira, A.M.S. and Martinez, E.Z. 2017. Availability of herbal medicines and medicinal plants in the primary health facilities of the state of São Paulo, Southeast Brazil: results from the National Program for Access and Quality Improvement in Primary Care. Ciencia \& Saude Coletiva. 22, 1651-1659.

3. Farnsworth, N.R. and Soejarto, D.D. 1985. Potential consequence of plant extinction in the United States on the current and future availability of prescription drugs. Econ. Bot. 39, 231-240.

4. Oyebode, O., Kandala, N.B., Chilton, P.J. and Lilford, R.J. 2016. Use of traditional medicine in middle-income countries: a WHO-SAGE study. Health Policy Plan. 31, 984-991.

5. Kemeuze, V.A. 2011. Marantochloa leucantha (K. Schum.) Milnne-Redh: Record from PROTA4U In: Brink, M. and Achigan-dako, E.G. (Editors). PROTA (Plant Resources of Tropical Africa/Resources Vegetales de I'Afrique Tropicale). Wageningen, Netherlands: PROTA, 812.

6. Ondo, J.P., Obame, L.C., Barhe, T.A., Akoue, G.N., Edouard, N.S.I. and Lebibi, J. 2011. Phytochemical screening, total phenolic content and antiradical activity of Asplenium africanum (Aspleniaceae) and fruit of Megaphrinium macrostachyum (Marantaceae).J. Appl. Pharma. Sci. 3, 92.

7. Sima, O.C., Ondo, J.P., Obame-Engonga, L.C., Padzys G.S., Zongo, C., Bongui, J.B., Nsi, E.E. and Traoré, S.A. 2016. Phytochemical screening, evaluation of antioxidant and antimicrobial properties of Erythrophleum ivorense A. Chev (Leguminosae) and Megaphrynium macrostachyum Benth (Marantaceae), medicinal plants from Gabon. Int. J. Biosci. 8, 43-53.

8. $\mathrm{Xu}, \mathrm{Z}$. and Chang, L. 2017. Marantaceae: Identification and Control of Common Weeds. Volume 3. Springer; Singapore. 913-916.

9. Vaghasiya, Y., Dave, R. and Chanda, S. 2011. Phytochemical analysis of some medicinal plants from western region of India. Res. J. Med. Plant. 5, 567-576.
10. Adeogun, O., Adekunle, A. and Ashafa, A. 2016. Chemical composition, lethality and antifungal activities of the extracts of leaf of Thaumatococcus daniellii against foodborne fungi. Beni-Suef Uni. J. Basic Appl. Sci. 5, 356-368.

11. Abdullah, Y., Schneider, B. and Petersen, M. 2008. Occurrence of rosmarinic acid, chlorogenic acid and rutin in Marantaceae species. Phytochem. Lett. 1, 199-203.

12. Giday, M., Asfaw, Z. and Woldu, Z. 2010. Ethnomedicinal study of plants used by Sheko ethnic group of Ethiopia. $J$. Ethnopharmacol. 132, 75-85.

13. Hamill, F.A., Apio, S., Mubiru, N.K., Bukenya-Ziraba, R., Mosango, M., Maganyi, O.W. and Soejarto, D.D. 2003. Traditional herbal drugs of Southern Uganda, II: literature analysis and antimicrobial assays. J. Ethnopharmacol. 84, 57-78.

14. Liu, F.T. and Rabinovich, G.A. 2010. Galectins: regulators of acute and chronic inflammation, Annals of the New York Acad. Sci. 1183, 158-182.

15. Horadagoda, N.U., Knox, K.G., Gibbs, H.A., Reid, S.W.J., Horadagoda, A., Edwards, S.E.R. and Eckersall, P.D. 1999. Acute phase proteins in cattle: discrimination between acute and chronic inflammation. Vet. Rec. 144, 437.

16. Agbaje, E.O., Adeneye, A.A. and Adeleke, T.I. 2008. Antinociceptive and anti-inflammatory effects of a Nigerian polyherbal tonic (PHT) extract in rodents. Afr. J. Compl. Alt. Med. 5, 399-408.

17. Gupta, M., Mazumder, U.K., Gomathi, P. and Thamilselvan, V. 2006. Anti-inflammatory evaluation of leaves of Plumeria acuminates. BMC Compl. Alt. Med. 36, 14721478.

18. Ayoola, G.A., Coker, H.A. and Adesegun, S.A. 2009. Phytochemical screening and antioxidant activities of some selected medicinal plants used for malaria therapy in Western Nigeria, Trop. J. Pharm. Res. 7, 1019-1024.

19. Aka, P.A. and Nwambie, A.I. 1994. Evaluation of Nigerian traditional medicines. Plants used for rheumatic (inflammatory) disorders. J. Ethnopharmacol. 42, 179-183.

20. Akira, S., Uematsu, S. and Takeuchi, O. 2006. Pathogen recognition and innate immunity. Cell 124, 783-801.

21. Harborne, J.B. 1998. Phytochemical methods. Vol. 1, Chapman and Hall, London, p. 113.

22. Lorke, D. 1983. A new approach to practical acute toxicity testing. Archiv. Toxicol. 54, 275-287.

23. Gyamfi, M.A., Yonamine, M. and Aniya, Y. 1999. Freeradical scavenging action of medicinal herbs from Ghana Thonningia sanguinea on experimentally-induced liver injuries. Gen. Pharmacol. 32, 661-667.

24. Sahreen, S., Khan, M.R. and Khan, R.A. 2010. Evaluation of antioxidant activities of various solvent extracts of Carissa opaca fruits. Food Chem. 122, 1205-1211. 
25. Winter, C.A., Risley, E.A. and Nuss, G.W. 1962. Carrageenan-induced oedema in the hind paw of rat as an assay for anti-inflammatory activity. Proc. Soc. Experi. Biol. Ther. 111, 544-547.

26. Middleton, E., Kandaswami, C. and Theoharides, T.C. 2000. The effects of plant flavonoids on mammalian cells: implications for inflammation, heart disease, and cancer. Pharmacol. Rev. 52, 673-751.

27. Dildar, A., Muhammad, M.K. and Ramsha, S. 2015. Comparative Analysis of phenolic flavonoids and antioxidant and antibacterial potential of methanolic, hexanic and aqueous extracts from Adiantum caudatum leaves. Antioxidant 4, 394-409.

28. Hernandez, N.E., Tereschuk, M.L. and Abdala, L.R. 2000. Antimicrobial activity of flavonoids in medicinal plants from Tafi Del Valle (Tucuman, Argentina). J. Ethnopharmacol. 73, 317-322.
29. Hodzic, Z., Pasalic, H., Memisevic, A., Scrabovic, M., Saletovic, M. and Poljakovic, M. 2009. The influence of total phenols content on antioxidant capacity in the whole grain extracts. Eur. J. Sci. Res. 28, 471-477.

30. Ikram, E.H.K., Eng, K.H., Jalil, A.M.M., Ismail, A., Idris, S., Azlan, A., Nazri, H.S.M., Diton, N.A.M. and Mokhtar, R.A.M. 2009. Antioxidant capacity and total phenolic content of Malaysian underutilized fruits. J. Food Comp. Anal. 22, 388-393.

31. Fu, L., Xu, B., Xu, X., Qin, X., Gan, R. and Li, H. 2010. Antioxidant capacities and total phenolic contents of 56 wild fruits from South China. Molecules 15, 8602-8617.

32. Pierre, B.K., Pierre Selim, H. and Tatjana, S. 2015. Study of polyphenol content and antioxidant capacity of Myrianthus arboreus (Cecropiaceae) root bark extracts. Antioxidant 4, 419-426. 